\title{
Delineating Turkic non-finite verb forms by syntactic function
}

\author{
Jonathan North Washington \& Francis M. Tyers *
}

\begin{abstract}
In this paper, we argue against the primary categories of non-finite verb used in the Turkology literature: "participle" (причастие <pričastije) and "converb" (деenричастие <dejepričastije ). We argue that both of these terms conflate several discrete phenomena, and that they furthermore are not coherent as umbrella terms for these phenomena. Based on detailed study of the non-finite verb morphology and syntax of a wide range of Turkic languages (presented here are Turkish, Kazakh, Kyrgyz, Tatar, Tuvan, and Sakha), we instead propose delineation of these categories according to their morphological and syntactic properties. Specifically, we propose that more accurate categories are verbal noun, verbal adjective, verbal adverb, and infinitive. This approach has far-reaching implications to the study of syntactic phenomena in Turkic languages, including phenomena ranging from relative clauses to clause chaining.
\end{abstract}

Keywords. non-finite verb forms; Turkic languages; converbs; participles

1. Introduction. In the Turkology literature, non-finite verb forms are categorised as either "participles" or "converbs" (corresponding respectively to причастие pričastije〉 and деenричастие 〈dejepričastije〉 in the Turkology literature in Russian). These terms are intended to explain the ways in which these morphemes (which are almost entirely suffixes) may be used. Sources from throughout the Turkology literature that group all non-finite forms in a given Turkic language into these two categories include ŞaBdan uulu \& Batmanov (1933) for Kyrgyz, Дыренкова (1941) for Shor, Убрятова et al. (1982) for Sakha, and Anderson \& Harrison (1999) for Tyvan.

We propose instead that the morphology and syntax of many Turkic languages present a clear distinction between verbal nouns, verbal adjectives, verbal adverbs, and infinitives. ${ }^{1}$ These non-finite forms are all inflected verb forms which maintain their internal argument structure but do not function independently as the main verb of a sentence. Verbal nouns, adjectives, and adverbs behave morphologically and syntactically (within other phrases) as their eponymous category, while infinitives obligatorily pattern with and form a single predicate with an auxiliary verb (which in turn may be finite or non-finite). Another way of understanding these categories is that the morphology that is used to create verbal nouns, adjectives, and adverbs allows a verb phrase to project to a noun phrase head, an adjective phrase head, or directly as an adjunct to another verb phrase, respectively, while infinitives collocate with auxiliaries to form a single verb phrase projection (which could in turn project to something else).

We set up morphological and syntactic criteria for distinguishing these four main types of non-finite verb in Turkic (section 5), and further examine the distribution of suffixes that form these different types of

\footnotetext{
* Based on collaborations with and input from: Aziyana Bayyr-ool, Çağrı Çöltekin, Memduh Gökırmak, Sardana Ivanovna, Tolgonay Kubatova, Aibek Makazhanov, and Ilnar Salimzyan. Furthmore, we appreciate the detailed feedback we've received from Donna Jo Napoli, several anonymous reviewers, and from the participants of Tu+4—especially Richard Larson, Chris Collins, and Michael Daniel. This paper is much more coherent because of these people. All errors in data, analysis, use of terminology, gaps in our understanding of syntax, etc., are our own. Authors: Jonathan North Washington, Swarthmore College (jonathan.washington@swarthmore.edu) \& Francis M. Tyers, Indiana University (ftyers@iu.edu).

${ }^{1}$ Note on terminology: it has been suggested that "verbal [POS]" may not be the most clear template for naming these categories as the terms could be parsed in a way that suggests that they refer to verb-like other part-of-speech instead of other-POS-like verbs. It has been suggested that it would be clearer to use terms like "nominal verb", "adjectival verb", and "adverbial verb" or similar. We have chosen to go with the "verbal [POS]" naming convention anyway, as there is precedent for these terms. Despite some variation in the literature on whether "verbal [POS]" refers to derived or inflected verb forms, in this paper "verbal [POS]" will be used to refer to inflected verb forms, while "deverbal [POS]" will be used to refer to derived verb forms. It should be understood that our arguments are independent of our naming convention, and that one may be problematised irrespective of the other.
} 
non-finite verbs in a geographically and genetically diverse range of Turkic languages (Kazakh, Kyrgyz, Tatar, Tuvan, Sakha, and Turkish; see section 5.2 for details). Based on this methodology, we argue that the categories "participle" and "converb" are insufficient to categorise non-finite verb forms in Turkic in that each term, as standardly used, conflates disparate morphosyntactic patterns. More specifically, we show both that non-finite verbal morphemes in Turkic languages may exhibit only some of the properties characteristic of either "participle" or "converb", and that they may also exhibit characteristics of more than one of the two categories.

Besides allowing for more cross-linguistic consistency in nomenclature, we believe that the approach we present in this paper yields more concise generalisations about the morphosyntactic interplay of these suffixes, including by offering a less ambiguous classification (see section 3 ). We also show that this scheme leads to less ambiguous representation, at a similar level as distinguishing between noun and adjective readings of individual words (cf. "red" in English, as discussed regarding Kazakh by Krejci \& Glass 2015). In many ways this work simply extends thinking on non-finite categorisation commonly referred to in the field of linguistics to Turkic-specific work (the field of Turkology), and argues against use of the languagefamily-specific terminology that is often used when discussing Turkic languages, which obscures commonalities and creates spurious differences.

While we use concepts from constituency and dependency syntax to clarify the presentation of our approach, we aim not to frame the approach as relying on any particular theoretical framework of syntax or morphology.

This paper is structured as followed: section 2 provides background on the traditional dichotomy, section 3 discusses the problem of ambiguity, section 4 overviews our proposal, section 5 explains further, providing morphological evidence from case studies, section 6 discusses phenomena related to non-finite verb forms that present challenges to our model, and section 7 concludes.

2. Background. The traditional dichotomy between participle and converb as used in the Turkology literature seems to have arisen mainly due to the fact that the suffixes that are used to create non-finite verb forms in Turkic languages cluster roughly in two groups. Specifically, many non-finite verbal suffixes in a given language that are used to create verbal adjectives may also be used to create verbal nouns (e.g., Turkish -/mIş/, Kazakh -/GAn/); these suffixes are often referred to as participle-forming suffixes. Likewise, many of the suffixes used to create verbal adverbs are also used to create infinitives (e.g., Tatar -/(I)p/, Kyrgyz -/GAnI/); these suffixes are often referred to as converb-forming suffixes. Full examples demonstrating that apparently ambiguous affixes of the two types may still have clearly unambiguous and distinct uses are presented in (1) for the former and (2) for the latter type.

a. "Participle" as a verbal noun in Kazakh

Маған кітапханаға барған ұнайды.

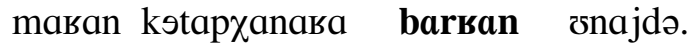

masan kstap $\chi a n a-G A$ bar-GAn sna-E-DI.

I.DAT library-DAT go-vN be.liked-NPST-3

'I like going to the library.'

b. "Participle" as a verbal adjective in Kazakh

Маған кітапханаға барған кісі ұнайды.

masan kэtapұапава barsan kэsэ вnajdə.

masan kstap $\chi a n a-G A$ bar-GAn kэsэ ona-E-DI.

I.DAT library-DAT go-vADJ person be.liked-NPST-3

'I like the/a person who went to the library.' 
a. "Converb" as an infinitive in Kyrgyz

Досум китепти китепканага тапшырганы турат.

dosum kitepti kitepqanara tap/ursanu turat.

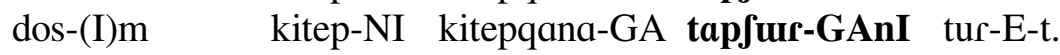

friend-POss.1sG book-ACC library-DAT turn.in-INF stand-NPST-3

'My friend is getting ready to return the book to the library.'

b. "Converb" as a verbal adverb in Kyrgyz

Досум китепти китепканага тапшырганы кезекте турат.

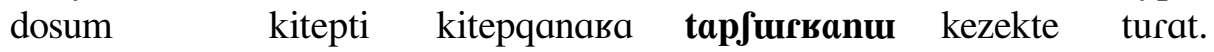

dos-(I)m kitep-NI kitepqana-GA tapfur-GAnI kezek-DA tur-E-t.

friend-Poss.1sg book-ACC library-DAT turn.in-vadv line-LOC stand-NPST-3

'My friend is standing in line in order to return the book to the library.'

The second sentence of each pair of examples differs from the first only in the addition of a single noun form (кісі [kэss] 'person' and кезекте [kezekte] 'in line', ${ }^{2}$ respectively). In (1a), the verbal noun form барған [barsan] heads a verb phrase which serves as the complement of the main verb, a role served in (1b) by the noun phrase headed by кici [kэsง] 'person', which in that example is modified by the verbal adjective form барған [вагьаn]. In (2b), the presence of the noun form кезекте [kezekte] 'in line' forces the verb form mypam [turat] to be read as a lexical verb ("stand") with the new noun form ("in line") as an adjunctand not an auxiliary needing an infinitive to pattern with as in (2a). This in turn forces the reading of manuыргань [tapfuгваnш] as a verbal adverb ("in order to return") and not an infinitive ("getting ready to return"). Johanson (1998) delineates three types of non-finite verbs (action nouns, participles, and converbs) in Turkic, and further (Johanson 1995) distinguishes several classes of converbs. This latter source is included in a volume that argues for "converb" as a single coherent category in the world's languages, a premise disputed by Zúñiga (1998). Furthermore, we believe that the delineation of these "types" of converb by Johanson (1995) demonstrates independently that the category is not fully coherent for Turkic languages either.

Johanson's (1995)'s "levels" 1 and 2 can be understood as verbal adverbs, differing primarily in whether the verbal adverb has a distinct subject from the main clause (level 1) or not (level 2), and possibly also in syntactic configuration. Level 4 corresponds exactly to infinitives. Level 3 is discussed further in section 6.3.

3. A problem: spurious ambiguity. An important motivation in our analysis is the desire to produce less ambiguous morphological analyses, and to take advantage of unequal distribution of ambiguity by nonfinite morpheme. In a two category system, there are participles and converbs. These can potentially be analysed in context as having a range of syntactic functions, for example a participle may be used as a subject, a complement clause or an adnominal modifier, while a converb may be a main predicate or an adverbial modifier of a verb. Let us take an example from Turkish, the suffixes -/dIk/ and -/(j)An/.

These two suffixes may both be classified in the traditional system as participles; they are used to modify nouns in a function similar to the relative clause. For example, gördï̈̆̈̈̈m ateş çıktı gözlerinden 'The fire I saw left from your eyes', ateşi gören insan 'The man who sees the fire'. They may also both be used with nominal morphology as headless relative clauses, as in gördüklerim '[the ones] I saw' and görenler '[the ones] who see'.

In addition, a -/dIk/ form may be used as a complement clause to another verb, whereas a -/(j)An/ form cannot. For example, parka gittiğimi gördün mü? 'did you see me walking in the park?' / 'did you see [the one] I was walking in the park?' is a -/dIk/ form which has a complement clause reading and a headless relative clause reading, but parka gideni gördün mü?, which can only mean 'did you see [the one] walking in the park', is a -/(j)An/ form where the complement clause reading is not possible, and only the head-

\footnotetext{
${ }^{2}$ Translations throughout the paper are given in fluent English for clarity, and morpheme-by-morpheme glosses are included when their use helps to illustrate a point.
} 
less relative clause reading is.

Why does this matter? Suppose we have an automatic parsing system that assigns syntactic functions to Turkic non-finite wordforms, and suppose for the purposes of this explanation that we have a reduced set of functions: complement clause and adnominal modifier, and clausal subject, (nominal) subject and (nominal) object (these latter two corresponding to the headless NP analyses above). If we treat -/dIk/ and -/(j)An/ the same morphologically (that is, the 'participle' analysis), we have two problems: (1) the morphological behaviour in adnominal modification is different: -/dIk/ requires an agreement morpheme, while -/(j)An/ does not; and (2) the wordforms produced by combining the two suffixes with a stem do not permit identical syntactic readings.

\begin{tabular}{|c|c|c|c|c|c|}
\hline & $\begin{array}{l}\text { complement } \\
\text { clause }\end{array}$ & $\begin{array}{c}\text { adnominal } \\
\text { modifier }\end{array}$ & $\begin{array}{l}\text { clausal } \\
\text { subject }\end{array}$ & $\begin{array}{c}\text { nominal } \\
\text { subject }\end{array}$ & $\begin{array}{c}\text { nominal } \\
\text { object }\end{array}$ \\
\hline gördüğ̈̈̈m & $\checkmark$ & $\checkmark$ & $\checkmark$ & $\checkmark$ & - \\
\hline gören & - & $\checkmark$ & - & - & - \\
\hline gördüklerim & - & - & $\nu$ & $\nu$ & - \\
\hline görenler & - & - & $\nu$ & $\nu$ & - \\
\hline gittiğimi & $\checkmark$ & - & - & - & $\checkmark$ \\
\hline gideni & - & - & - & - & $\checkmark$ \\
\hline
\end{tabular}

Table 1: Table showing potential ambiguity of Turkish verb forms in terms of syntactic readings.

If we assign possible syntactic readings simply on the basis of case, then the forms gittiğimi and gideni would receive the same number of potential readings (2 potential readings each), as would the forms gördü̈̆üm and gören (4 potential readings each). This would lead to an average number of potential readings per form in Table 1 of $2 \frac{2}{3}$. By following the approach we outline in $\$ 4$, we are able to reduce this to 2 . Reducing spurious ambiguity in analysis is an important aid to effective automatic processing.

4. Our proposal: a four category approach. Under our proposal, a form may be categorised based both on its morphotactics (that is, which morphemes may attach to it) and also on its syntactic distribution. Hence, there is a relationship between the non-finite verb type and its interaction with other phrases.

Our analysis is based on an understanding of Turkic non-finite verb forms as inflected forms of a verb, and not as derived forms of a verb. ${ }^{3}$ The verb phrase headed by a non-finite verb maintains its internal argument structure, but the non-finite morphology allows the whole verb phrase to be used in a functionally different way from a finite verb form. This verb form then behaves similarly to phrases of other types: e.g., verb phrases headed by a verbal nouns function like noun phrases, and, like a noun phrase, may take possessive morphology and case morphology and/or postpositions.

4.1. Verbal nOuns. As mentioned above, Turkic verbal noun morphology enables a verb phrase headed by the verbal noun to head a nominal phrase and take nominal morphology. Hence the phrases headed by verbal nouns may either be arguments of another verb (such as subject or object) or have an adverbial or adjunct relationship to another verb when appearing with an adverbial case marker or a postposition. As with all of the non-finite verb forms, Turkic verbal nouns may occur with all internal arguments (and adjuncts) intact, and it is understood that the entire verb phrase is used as a nominal head. Possessive morphology (matching that used with other noun phrases) is also frequently used with verbal noun forms in Turkic languages, often agreeing in person and number with an "extracted" subject in genitive case (for a different analysis of this construction in Uyghur, see Asarina \& Hartman 2011).

We have not identified any examples of verbal nouns in Turkic languages occurring with dependent adjectives or determiners, and verbal nouns further exhibit restrictions regarding the use of plural morphol-

\footnotetext{
${ }^{3}$ Some affixes may be used inflectionally and derivationally, so inflected non-finite verb forms have the potential to be be ambiguous with derived forms of verbs, discussed below regarding example (7).
} 
ogy. In an extreme case, Tuvan verbal nouns in -/GAlAK/ appear to only occur in locative case-in which case it may be possible to say that -/GAlAKtA/ is on the way to grammaticalising into a verbal-adverbforming suffix.

Verbal nouns are often referred to as gerunds in the linguistics literature (e.g., Ross 2016). In some Turkology sources—Erdal (2004: §3.28) and Krueger (1961: 156-158)—nominative-case (and perhaps accusativecase) verbal nouns are referred to as "infinitives".

4.2. Verbal adjectives. Verbal adjectives have an attributive function and modify nominals. In doing so, they also form one of the main strategies available to Turkic languages for forming relative clauses, where the modified noun may be understood to be "extracted" (or similar) from the verb phrase headed by the verbal adjective.

In (1b), the word кici [kэs९] 'person' is modified by the verbal adjective барған [barsan] 'who went'. More accurately, the noun is modified by the verbal adjective phrase кітапханаға барған [kэtapхапава barваn] 'who went to the library'. It may also be noted that this phrase is a relative clause where $\kappa i c i$ [kэsэ] 'person' would be the subject of the unrelativised version.

Verbal adjectives in Turkic often may not be modified by adverbs, nor may receive comparative morphology (in those Turkic languages which add a suffix to adjectives to indicate comparative). In a few Turkic languages (including Turkish), some verbal adjectives receive agreement marking with the subject in a form similar to a nominal possessive marker (discussed by e.g., Csató \& Uchturpani 2010).

Verbal adjectives are often referred to as participles in the linguistics literature (e.g., Ross 2016); however, this is distinct from the use of the term "participle" in the Turkology literature, as the former encompasses only verbal adjectives and not any subset of verbal nouns like the latter does.

4.3. Verbal adverbs. A verbal adverb in Turkic languages heads a verb phrase that is subordinate to another verb, and is understood to have an adverbial function. Semantically, the use of a particular verbal adverb suffix often conveys a specific type of temporal or causal relationship between the two verb phrases.

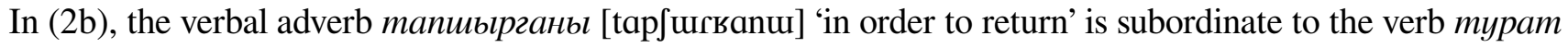
[turat] 'stands', and the subordinated phrase китепти китепканага тапшырганыл [kitepti kitepqanaва tap[шгваnш] 'in order to return the book' adds a reason to the main verb phrase Досум кезекте турат [dosum kezekte turat] 'My friend is standing in line.'

(3) Conditional verbal adverb in Kyrgyz

$\begin{array}{llllll}\text { Сен } & \text { бираз кечиксең } & \text { досум } & \text { кетип } & \text { калмак. } \\ \text { sen } & \text { biraz } & \text { ketfiksey } & \text { dosum } & \text { ketip } & \text { qałmaq } \\ \text { sen } & \text { biraz } & \text { ketfik-sA-y } & \text { dos-(I)m } & \text { ket-(I)p } & \text { qał-mAq }\end{array}$

you.SG.INFM a.little be.late-vaDv-2SG.INFM friend-POSs.1sG leave-INF PERF-IRR.3

'If you had been a little late, my friend would have left.'

In many Turkic languages, verb forms that are often referred to as conditional ${ }^{4}$ are verbal adverbs that uniquely agree in person and number with a subject, which, like with other verbal adverbs, may or may not be the same as the subject of the main verb (in (2b), the verbal adverb and the main verb share a subject). The example in (3) shows the conditional verbal adverb agreeing with a different subject than the main verb in person, number, and formality. In this case, the verbal adverb and its subject form an adverbial clause which is an adjunct to the main verb phrase.

Verbal adverbs are often referred to as converbs in the linguistics literature (e.g., Ross 2016); however, this is often distinct from the use of the term "converb" in the Turkology literature, as the former may encompass only verbal adverbs and the latter includes what we call infinitives as well.

\footnotetext{
${ }^{4}$ In other language families, "conditional mood" usually refers to a property of finite verb forms; in Turkic, the forms referred to as "conditional" are always subordinate to another verb in a way that only verbal adverbs, under our categorisation, may be.
} 
It is also worth noting that the descriptions of some of the suffixes that form verbal adverbs are discussed in the literature on Turkic languages as being "verbal conjunction morphemes", for example Krueger (1961: 163-164) for Chuvash and Kornfilt (1997: pp. 21-23, §1.3.1.5, §2.1.3.6.7) and Göksel \& Kerslake (2005: ch. 28) for Turkish. However, in these descriptions, no formal or semantic criteria (for example those discussed by Haspelmath 2006) are given to motivate the separation of this particular set of verbal adverb suffixes from the larger class of subordinating verbal adverbs. We see the semantics of conjunction as being naturally extremely similar to the semantics conveyed by a subordination relation indicating simultaneity or sequential occurrence, as verbal adverb forms often do.

4.4. InFINITIVES. Infinitives in Turkic languages are verb forms that collocate with and serve as a single verb phrase projection with auxiliaries. Auxiliaries are a fairly small lexical class in most Turkic languages, discussed in depth for Kazakh by Demirci (2003) and Muhamedowa (2016: §1.15). The infinitive phrase forms a single predicate with the auxiliary (as noted also by Sugar 2019), and unlike verbal adverbs, there may only be one external argument (subject). In Turkic languages, the combination of a given infinitive form and a given auxiliaries conveys specific aspectual or modal information. The auxiliary is the sole bearer of inflection for tense and subject agreement, or may in turn be inflected as non-finite. In (2a), the infini-

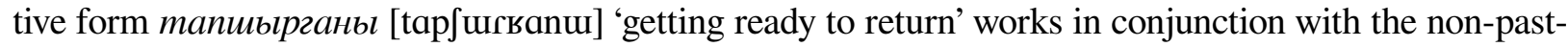
, third-person-inflected auxiliary mypam [turat] to convey the sense 'is getting ready to return'.

It should be noted that of the languages surveyed, Turkish had the least infinitive forms. Based on Turkish orthography, the only infinitive in Turkish is in $-/(\mathrm{j}) \mathrm{Ip} /$, and the only auxiliary is $d u r$, resulting in phrases like that in (4a). Under the same analysis (i.e., the interpretation of orthographic spaces as word boundaries), a number of other infinitive + auxiliary phrases have grammaticalised to modal and aspectual morphemes (cf., Kornfilt 1997: §2.1.3.3-2.1.3.4), such as that in (4b). ${ }^{5}$ However, it should be noted that despite the apparent grammaticalisation of these forms, they may still occasionally appear separated, e.g., by da 'and': Yarın yă̆mur yă̆a da bilir, yağmaya da bilir 'Tomorrow it might rain and it might not rain' (cf., Kornfilt 1997: 550).

(4) a. The only infinitive + auxiliary construction per Turkish orthography

$\begin{array}{lll}\text { Şark1 } & \text { söyleyip } & \text { durdu. } \\ \text { Jarku } & \text { søjlejip } & \text { durdu } \\ \text { Jarku } & \text { søjle-(j)Ip } & \text { dur-DI } \\ \text { song } \quad \text { say-INF } & \text { KEEP-PST.3 } \\ \text { 'S/he kept singing.' }\end{array}$

b. The durative in Turkish as a grammaticalised infinitive+auxiliary construction Şark1 söyleyedurdu. jarku søjlejedurdu farku søjle-(j)Adur-DI song say-DUR-PST.3 'S/he sang for a while.'

4.5. Potential ambiguity of Verbal nouns AND verbal adjectives. Verbal adjectives may often be substantivised. This is usually apparent through the addition of nominal morphology, such as nominal possessive morphemes, the plural morpheme, or case morphemes. ${ }^{6}$ An example is shown in (5).

(5) Nominal use of a verbal adjective in Kazakh

\begin{tabular}{|c|c|c|}
\hline $\begin{array}{l}\text { Кітапханаға } \\
\text { kэtapхапава }\end{array}$ & $\begin{array}{l}\text { барғандарды } \\
\text { barwandardə }\end{array}$ & $\begin{array}{l}\text { ұнатамын. } \\
\text { snatamən. }\end{array}$ \\
\hline kstap $\chi a n a-G A$ & bar-GAn-LAr-NI & øna-t-E-MIn. \\
\hline $\begin{array}{l}\text { library-DAT } \\
\text { 'I like goings to }\end{array}$ & $\begin{array}{l}\text { go-VADJ-PL-ACC } \\
\text { the library.' }\end{array}$ & be.liked-CAUS-NPST-1sG \\
\hline
\end{tabular}

(verbal noun reading) (verbal adjective reading)

\footnotetext{
${ }^{5}$ Other examples include -/(j)Abil/ as in bakabilir 'can look', -/(j)Akal/ bakakaldı 'looked on as', -/(j)Iver/ bakıverdi 'took a look', and -/Ijor/ baklyor 'is looking'.

${ }^{6}$ One way to understand this is to consider the verb phrase to be part of an adjective phrase that is in turn part of a noun phrase with an empty nominal head.
} 
It is not possible to parse this form as a verbal noun. This seems to be due in part to the fact that the semantics of the plural morpheme do not appear to be compatible with verbal nouns in most Turkic languages. Truly ambiguous examples are difficult to identify.

4.6. Potential ambiguity of Verbal adverbs and infinitives. Because of both the conflation of non-finite verbal categories by Turkologists (as above) and linguists (e.g., Sugar 2019) and the similarity of the sets of morphemes used for the conflated categories throughout the morphology of Turkic languages, ${ }^{7}$ there has been much written on the so-called ambiguity of $\mathrm{V}+\mathrm{V}$ sequences in Turkic languages (most recently Danka 2018, Karakoç 2018, Nevskaya, Jumabai \& Tazhibayeva 2018). Understanding these ambiguities and how they pattern cross-linguistically is key to understanding sentence and predicate structure. For example, in Sakha, аһаан барда [aha:n barda] can mean either 'started to eat' or 'ate and left' (Popova 2018). Once the category of "converb" is split into the categories of infinitives and verbal adverbs (6), the reason for this ambiguity between one- and two-predicate readings becomes obvious. This also requires recognising that one use of the verb бap [bar] 'go' is as an auxiliary that conveys inchoative aspect (i.e., the form is ambiguous between an intransitive verb and an auxiliary), and that the morpheme -/(A)n/ may be used in multiple ways (i.e., it may form both infinitives and verbal adverbs).

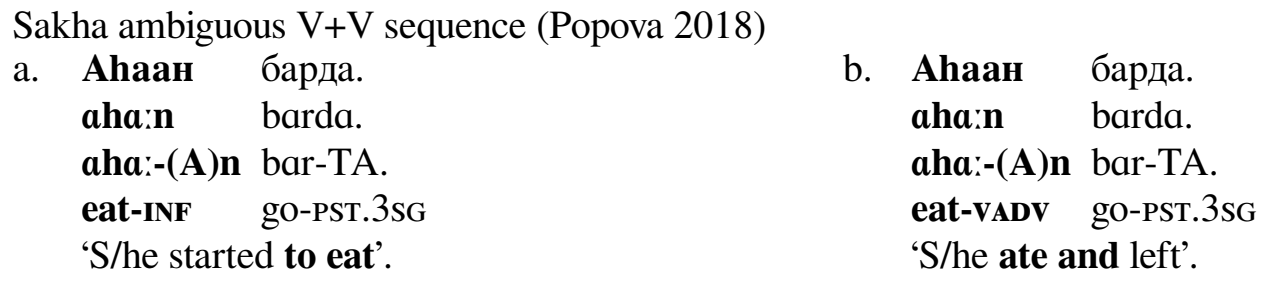

4.7. Note ON VERBAL NOUN FORMS COMMONLY REFERRED TO AS INFINITIVES. It should be noted that the nonfinite forms we refer to as infinitives are not the set of non-finite forms that are often referred to as infinitives in the literature on Turkic languages. Examples of forms that are often called infinitives in Turkic languages including forms in -/(I)w/ in Kazakh, -/(U)U/ in Kyrgyz, -/(A I)rGA/ and -/U (I)w/ in Tatar, and $-/ \mathrm{mA} /$ and $-/ \mathrm{mAk} /$ in Turkish. For us, these all straightforwardly form verbal nouns, and not infinitivesthey are used in the same places other verbal-noun-forming suffixes are used, and not where infinitive-forming suffixes are used-so we see no reason to categorise them separately. We believe that the use of these forms as clausal subjects and the fact that they tend to be the forms used for dictionary entries may be related to the reasons they are referred to as infinitives.

In the case of Turkish -/mAk/, there is a reading that is infinitive-like under our approach, but we maintain that it is a verbal noun. For example, the construction içmek istiyorum 'I want to drink' is parallel to the construction birayı istiyorum 'I want the beer', where iste- 'want' takes a complement in both. This is in contrast to an expression like içip durdum 'I kept drinking incessantly', where the auxiliary dur-never takes a complement. Also, in içmek istiyorum 'I want to drink', there are two separate events (DRINK and WANT) with a relation between them, whereas in içip durdum 'I kept drinking incessantly' there is only one event, with additional temporal semantics added by the auxiliary.

4.8. 'Verbal' AND 'DEVERBAL'. Inflected and derived forms may be ambiguous in many Turkic languages. That is to say that the same affixes used for non-finite verb forms often has some overlap with the set of affixes used to derive words of other parts of speech from verbs.

As an example, verbal nouns (inflected non-finite verb forms) may be ambiguous with deverbal nouns (nouns derived from verbs). One of the key differences is that non-finite verb forms maintain full internal argu-

\footnotetext{
7 While some authors (Ross 2016, Ylikoski 2003) use the term "converb" to refer solely to our "verbal adverbs" and the term "participle" to refer to our "verbal adjective", the Turkology literature additionally includes infinitives under the term "converb" and often includes verbal nouns under the term "participle" (e.g., Erdal 2004: §3.28, who calls all verbal noun forms either "participles" or "infinitives").
} 
ment (and adjunct) structure, while use of the same arguments (and adjuncts) with derived forms requires different inflectional strategies.

One of many examples of this ambiguity is the form жарыльии [dzarułuf] in Kyrgyz, from verb жарыл [dzaruł] 'explode' (itself passive of жар [dzar] 'make explode'). The form жарыльиш [dzarułu]] can be a verbal noun (inflected form) meaning 'exploding', as shown in (7a), or a deverbal noun (derivational form) meaning 'explosion', as shown in (7b).

a. $\quad$ Verbal noun from жар-ьыл- 'explode' in Kyrgyz
Дөңгөлөк чоң жолдо
жарылышы
мүмкүн.
døygøløk tfon dzołdo dzarułufu
mymkyn
døygøløk
ton dzot-DA
dłar-(I)L-(I) $\int-(\mathbf{s}) \mathbf{I}(\mathbf{n})$
mymkyn- $\varnothing$
tyre big road-LOC make.explode-PASs-vN-Poss.3 possible-COP.NPST.3
'The tyre might explode on the highway.'

b. Deverbal noun from жар-ыл- 'explode' in Kyrgyz

\begin{tabular}{|c|c|c|c|c|}
\hline $\begin{array}{ll}\text { Iоң жолдогу } \\
\text { on } & \text { dzołdoвu } \\
\text { on } & \text { dzoł-DA-GI } \\
\text { ig } & \text { road-LOC-ATTR }\end{array}$ & $\begin{array}{l}\text { дөңгөлөктүн } \\
\text { døygøløktyn } \\
\text { døygøløk-NIn } \\
\text { tyre-GEN }\end{array}$ & 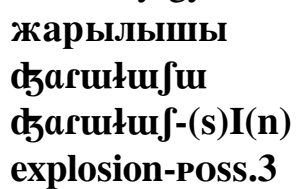 & $\begin{array}{l}\text { өтө } \\
\varnothing t \varnothing \\
\varnothing t \varnothing \\
\text { very }\end{array}$ & $\begin{array}{l}\text { кайгылуу } \\
\text { qајьшłu: } \\
\text { qajьu-LU: } \\
\text { woe-full }\end{array}$ \\
\hline
\end{tabular}

'The explosion of the tyre on the highway was really awful.'

In (7a), the verbal noun clause has a nominative subject and an adverbial case-marked adjunct чоң жолдо [tgon dzołdo] 'on the highway', and the full nominalised verb phrase is the subject of the copula sentence. In (7b), however, the deverbal noun is the head for an attributive form чоң жолдогу [tfon dzołdoвu] 'on the highway' (corresponding to the adjunct), and the "subject" is in genitive case. This noun phrase serves as the subject of the main verb. Crucially, the predicates of these two sentences cannot simply be switched:

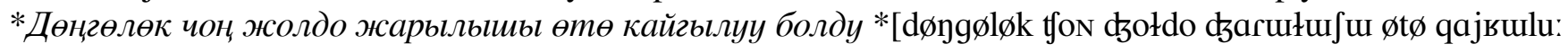

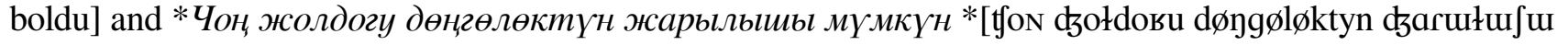
mymkyn] are both ungrammatical in Kyrgyz. While the situation appears to be somewhat more complicated than we have space to show here, we believe that verbal nouns and deverbal nouns may be distinguished along these general lines.

5. The incoherence of a two-category approach. Despite the fact that a number of morphemes are ambiguous within the categories that are often conflated, it is far from the case that all morphemes in a given Turkic language are ambiguous in this way.

The basic argument is that, first of all, not all non-finite-verb-forming suffixes can be used to create nonfinite verb forms of more than one function: to give some [unrelated] examples, Turkish -/(j)I $\int /$ (as in gidiş 'going') appears to only be able to form verbal nouns and not verbal adjectives, Kyrgyz -/GIs/ (as in унутулгус [unutułsus] 'unable to be forgotten') can only be used to form verbal adjectives and not verbal nouns, and Tuvan -/GAlA/ (as in дүшкеле [dy[kele] 'since falling') can only be used to form verbal adverbs and not infinitives. This type of observation serves as further evidence for the division of these categories based on syntactic function. Additionally, not all non-finite-verb-forming suffixes pattern in the traditional groupings; e.g., Tuvan -/GIze/ forms verbal adverbs and verbal nouns.

A systematic study of the full range of non-finite-verb-forming suffixes in Tuvan is presented in Washington et al. (2016), and similar studies have been conducted for previous work (Washington, Ipasov \& Tyers 2012, Washington, Salimzyanov \& Tyers 2014) and ongoing work (e.g., for Sakha). Including published and as of yet unpublished studies, related work is ongoing for around 20 Turkic languages. This section presents the range of uses of most non-finite-verb-forming suffixes in six Turkic languages, representing a sample of our ongoing work. 
5.1. Methodology. To determine the morpho-syntactic status of each suffix, we consulted with native speaker linguists and examined occurrences in corpora, led by descriptions and examples provided in grammatical descriptions of the languages.

The criteria used to determine that a suffix can be used in a particular function are outlined below. In all cases, the forms must demonstrate an ability for internal arguments and adjuncts to occur with them.

Verbal-noun-forming suffixes only occur with forms that:

- are witnessed serving as complement or subject of another verb, or

- are attested in at least two case forms (morphologically marked and/or unmarked). ${ }^{8}$

For example, the form барған [bагьаn] 'going' in (1a) serves as the subject of the main verb ұнайды [эnajdə] 'is liked'. In (8) - a sentence with the same translation but a causative main verb-the form барғанды [barваndə] 'going' (together with its adjunct) is the complement of the main verb ұнamaмblн [onatamən] 'I like'.

(8) Kazakh verbal noun as complement of another verb

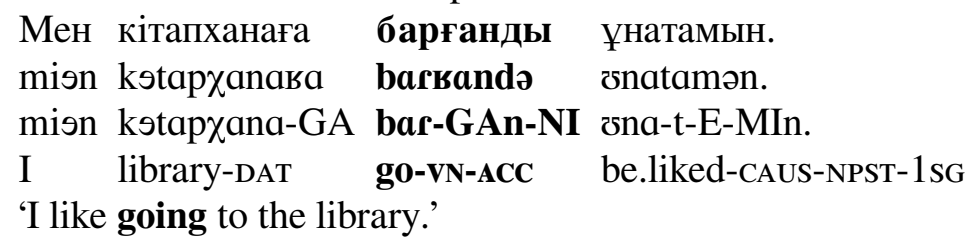

In the two examples, the form кітапханаға [kstapұanaвa] 'to the library' constitutes an adjunct, providing evidence that we are dealing with an inflected non-finite verb form and not a derived form. Furthermore, the two forms барған [bагваn] and барғанды [bагваndə] are both forms of the verb бар [bar] 'go' with a suffix -/GAn/; the former is not marked for case (which should be considered nominative case here) and is the subject of another verb, while the latter includes the accusative case morpheme and serves as the complement of another verb. Hence, -/GAn/ satisfies both criteria (the first one doubly) and may be considered a suffix that forms verbal nouns.

Suffixes that form verbal adjectives may only mark verb forms that:

- collocate with (generally preceding, in Turkic) and modify a nominal head, or

- modify an empty nominal head (project to an AP that in turn directly projects to a noun phrase, via which nominal morphology may be added-see Section 4.5).

Example (1b) from section 2 demonstrates the first criterion, with барған [barвan] 'who went' modifying кici [kэsэ] 'person'. An example of the second criterion is in (5), where барғандарды [barвandardə] 'the ones who go' can be understood as a verbal adjective phrase кітапханаға барған [kstapхапава barваn] 'who go(es)/went to the library' which projects directly to a noun phrase, via which the plural (here - $\partial a p$ [dar]) and accusative (here $-\partial b l[\mathrm{~d} ə]$ ) suffixes are added, resulting in an interpretation along the lines of 'the ones who go/went to the library'.

Suffixes that form verbal adverbs may only mark verb forms that:

- occur as an adjunct to another verb form, and

- are not transparently a verbal noun form inflected for case; i.e., a verbal adverb cannot appear to be composed of a verbal noun suffix that occurs in at least one other case form (morphologically marked or not) and a case-like form that occurs productively in the language. ${ }^{9}$

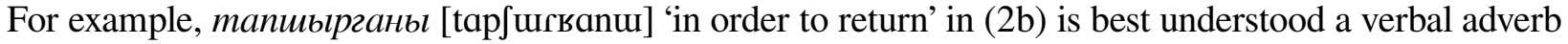
in Kyrgyz-despite -/GAnI/ likely having an etymological relationship to the verbal noun suffix -/GAn/-

\footnotetext{
${ }^{8}$ The reason for needing at least two case forms is so that some level of productivity can be demonstrated and so that we can be sure that we are not dealing with a single grammaticalised form, such as a verbal-adverb-forming suffix that was originally a verbal noun plus an adverbial case suffix, where at least one of the two suffixes is no longer productive. See Section 6.4 for further discussion on the grammaticalisation of non-finite verb forms.

${ }^{9}$ See Section 6.4 for more discussion on the reasoning for this.
} 
since the relationship between two is not morphologically transparent. In contrast, the forms manubı-

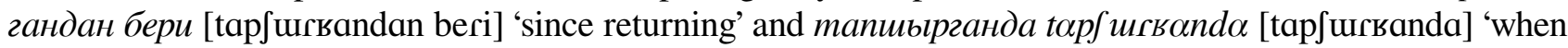
returning ${ }^{10}$ are verbal noun forms and not verbal adverb forms, since they are both transparently composed of the suffix -/GAn/ and case suffixes and postpositions -/DAn beri/ 'ABL since' and -/DA/ 'LOc', respectively, which, crucially, are productive in the nominal morphology of the language. This also serves as further evidence that $-/ \mathrm{GAn} /$ is used to form verbal nouns.

Suffixes that form infinitives may only mark verb forms that:

- collocate exclusively with (generally preceding, in Turkic) auxiliaries, and

- constitute a single predicate together with an auxiliary.

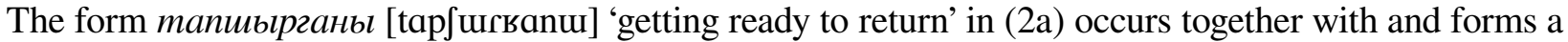
single predicate with the auxiliary form mypam [turat], which as a lexical verb would be glossed 'stands'. Many auxiliaries in Turkic languages are identical to lexical verbs, and probably all Turkic auxiliaries can be understood to be grammaticalised lexical verbs-so further criteria are needed to identify auxiliaries. Aside from being "semantically bleached" in relation to corresponding lexical verbs and instead conveying aspectual or modal semantics, the main syntactic test for auxiliary status in Turkic languages are whether the verb can form a single predicate with another verb (in an infinitive form, by definition). This criterion is not circular, since the parallel criteria for infinitive forms and status as an auxiliary are part of the following single criterion: two or more verb forms functioning as a single predicate in a Turkic language constitute an infinitive verb form and an auxiliary. Note that auxiliaries may be stacked using infinitive morphology.

5.2. The Languages. The map in Figure 1 shows the distribution of most modern Turkic-speaking communities ${ }^{11}$ with the geographic extent of the areas where the six languages examined in the case studies are mainly spoken indicated with ellipses: Turkish, Tatar, Kazakh, Kyrgyz, Tuvan, and Sakha.

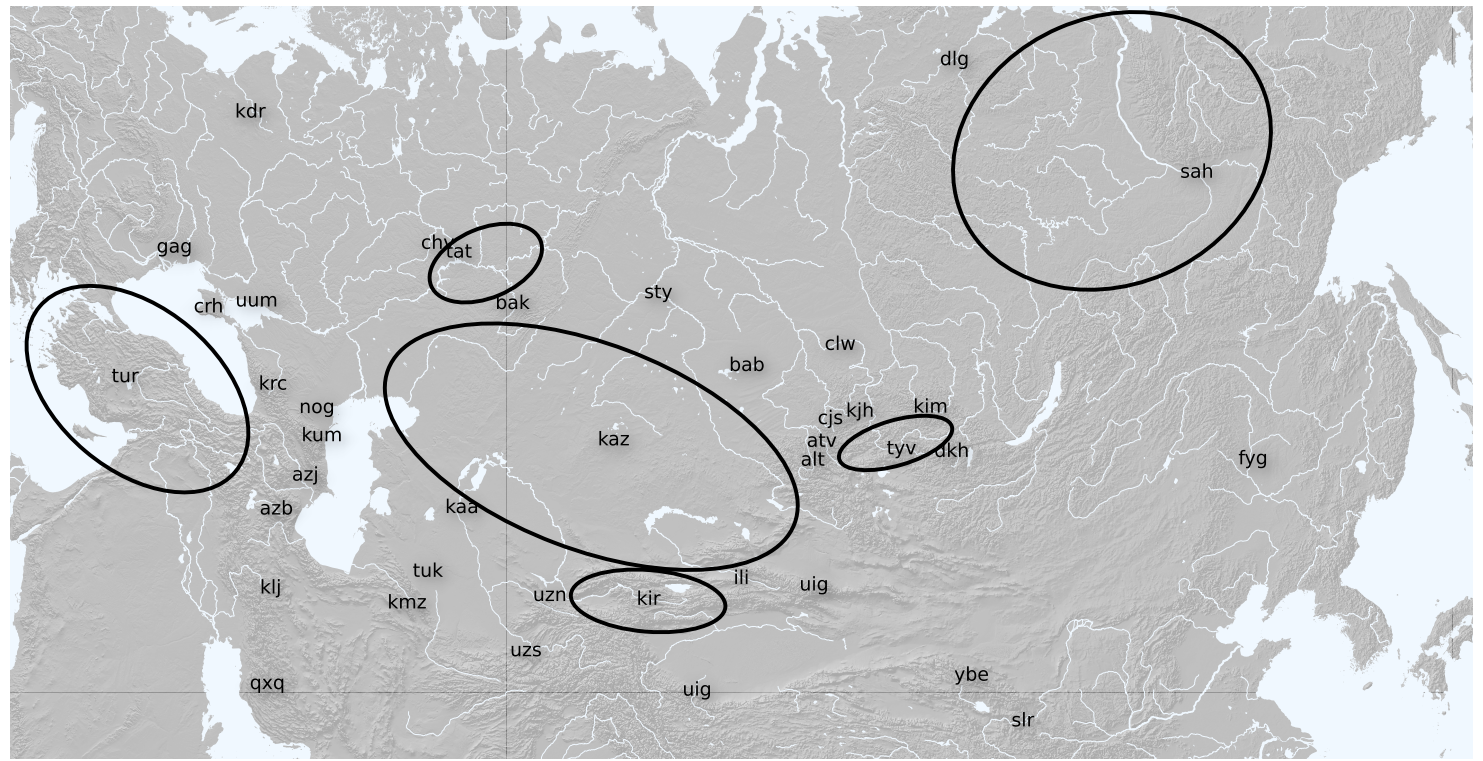

Figure 1: A map of Turkic languages showing the areas where the six case study languages are mainly spoken (circled areas) in relation to other Turkic languages.

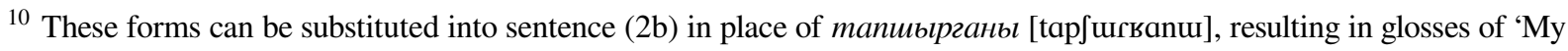
friend has been standing in line since s/he returned the book to the library' and 'My friend stands in line when s/he returns the book to the library,' respectively.

${ }^{11}$ Each language is represented with an ISO 693-3 code, with the exception of Ili Turkic (ili), Baraba Tatar (bab), and Fu-yü Gyrgys (fyg), which have not been assigned official codes.
} 
This group of languages is both geographically and phylogenetically diverse: on the periphary are Turkish, and Sakha, and Tuvan-members of the Oghuz, Sayan, and Lena Turkic branches, respectively. More centrally are three Kypchak Turkic varieties: Tatar, Kazakh, and Kyrgyz—each from a separate branch of Kypchak (the largest branch of Turkic in terms of number of languages).

5.3. The DATA. This data is presented in the form of a table for each language that lists the suffixes, with a check mark $(\boldsymbol{V})$ for each possible use of that suffix as a verbal noun, verbal adjective, verbal adverb, and infinitive. The list of suffixes is not meant to be exhaustive for each language, but to cover the majority of suffixes that are used to create non-finite verb forms.

As seen in Table 2, there is some tendency towards the existence of the groups "participles" (verbal-nounforming suffixes and verbal-adjective-forming suffixes) and "converbs" (verbal-adverb-forming suffixes and infinitive-forming suffixes). However, not one of these languages is consistent in this grouping: some verbal-noun-forming suffixes may not be used to form verbal adjectives (and vice versa), and some verbaladverb-forming suffixes may not be used to form infinitives (and vice versa).

It is also seen in Tuvan that two suffixes cross the boundaries of these two categories: -/GIze/ can be used to form verbal nouns and verbal adverbs, and -/GI dey/ can be used to form verbal adjectives (cf. Anderson \& Harrison 1999: ex. (121)) and verbal adverbs. Despite the tendency towards a two-category grouping, the ability for suffixes to be more limited in their use as well as the overlap between the categories suggest that at least a four-category classification is needed.

6. Further work. A range of phenomena that we are not currently able to fully handle under our analysis is discussed in this section. Understanding these topics is important for further work on non-finite verbs in Turkic languages. It should be noted that while we have not discussed polarity, most non-finite verbal forms appear to be able to be either affirmative or negative-the latter often with the addition of a negative verbal morpheme after the verb stem and before the non-finite verbal suffix.

6.1. Non-finite Forms with Copulas. A further open question is how to deal with single predicates that appear to be formed from verbal nouns or adjectives followed by forms that normally only occur as copulas, such as the examples in (9).

A single predicate formed from a non-finite verb form and a copula in Kazakh (a) and Kyrgyz (b)

$\begin{array}{ll}\text { a. Барған едім. } \\ \text { bагваn iэdэm } \\ \text { bar-GAn } & \text { iэ-DI-(I)m } \\ \text { go-vN? COP-PST-1sG } \\ \text { 'I had gone'. }\end{array}$
b. Барсам экен.
barsam eken
bar-sA-m eken- $\varnothing$
go-VADV?-1sg MIR-COP.NPST.3
'I wish I could go'.

If we say that the defective copula verb in these examples is an auxiliary, then we must say that -/GAn/ forms infinitives, in addition to verbal nouns and adjectives as described above. If we say that the construction is simply a verbal adjective or noun that forms a predicate using a copula verb that agrees with the subject of the sentence, then we take a purely etymological stance on the matter, and may end up declaring many other finite verb forms in Turkic languages to be copula constructions with non-finite verb formsperhaps attempting to draw a line to exclude forms which are not easily recognisable as containing a nonfinite verb form without diachronic data to support such an analysis. Further discussion of this issue within the framework of grammaticalisation may be found in section 6.4.

6.2. Volitional: a verbal noun?. There are also affixes which behave in a peripheral way, in that they create forms not enitrely like other non-finite forms in the same category.

An example of this is the volitional (or desiderative) suffix in some Turkic languages (/-GI/ in Kazakh, Kyrgyz, Karakalpak, and Bashqort, -/GU/ in Uyghur, -/gi/ in Uzbek, -/(A)sI/ in Tatar, -/(j)AsI/ in Turkish). There is evidence that this suffix creates verbal nouns: a possessive(-like) morpheme follows the suffix, 


\begin{tabular}{|c|c|c|c|c|c|}
\hline morpheme & example form & $\mathrm{vN}$ & VADJ & VADV & INF \\
\hline$-\mathrm{mI} \int$ & içmiş & $\checkmark$ & $\checkmark$ & & \\
\hline -dIk & içtik & $\checkmark$ & $\checkmark$ & & \\
\hline$-(\mathrm{j}) \mathrm{AcAk}$ & içecek & $\checkmark$ & $\checkmark$ & & \\
\hline$-(\mathrm{V}) \mathrm{r}$ & içer & $\checkmark$ & $\checkmark$ & & \\
\hline$-m A$ & içme & $\checkmark$ & & & \\
\hline$-m A k$ & içmek & $\checkmark$ & & & \\
\hline$-(\mathrm{j}) \mathrm{I} \int$ & içiş & $\checkmark$ & & & \\
\hline -(j)An & içen & & $\checkmark$ & & \\
\hline -(V)rken & içerken & & & $\checkmark$ & \\
\hline -(j)ArAk & içerek & & & $\checkmark$ & \\
\hline$-(\mathrm{j}) \operatorname{Ind} \mathrm{H}_{3} \mathrm{~A}$ & içince & & & $\checkmark$ & \\
\hline -(j)Ip & içip & & & $\checkmark$ & 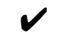 \\
\hline$-\mathrm{sA}$ & içse & & & $\checkmark$ & \\
\hline
\end{tabular}

\begin{tabular}{|c|c|c|c|c|c|}
\hline morpheme & example form & vN & VADJ & VADV & INF \\
\hline$-\mathrm{Ar}$ & uhэp & $\checkmark$ & $\checkmark$ & & \\
\hline -BIt & ucnum & $\checkmark$ & $v$ & & \\
\hline$-\mathrm{IAx}$ & иһиэх & $\checkmark$ & $v$ & & \\
\hline -A ilik & иһэ илик & $\checkmark$ & 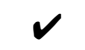 & & \\
\hline -IAn & иһиэ & $\checkmark$ & & & \\
\hline$-D A x$ & истэххэ & $\checkmark$ & & & \\
\hline$-\operatorname{AAtg} I$ & иһээччи & $\checkmark$ & & & \\
\hline$-(\mathrm{A}) \mathrm{n}$ & иһэн & & & $\checkmark$ & $\checkmark$ \\
\hline$-A$ & uhэ & & & $\checkmark$ & $\checkmark$ \\
\hline$-\operatorname{ImInA}$ & иһиминэ & & & $\checkmark$ & \\
\hline -BAkkA & испэккэ & & & $v$ & \\
\hline -AArI & иһээри & & & $\checkmark$ & \\
\hline
\end{tabular}

(a) Turkish; example forms are from the verb iç- 'drink'.

(b) Sakha; example forms from the verb $u c$ - [is] 'drink'.

\begin{tabular}{|c|c|c|c|c|c|}
\hline morpheme & example form & $\mathrm{vN}$ & VADJ & VADV & INF \\
\hline -GAn & ішкен & $\boldsymbol{V}$ & $\checkmark$ & & \\
\hline -EtIn & ішетін & $\checkmark$ & $\checkmark$ & & \\
\hline$-(\mathrm{A}) \mathrm{r}$ & ішер & $\checkmark$ & $\checkmark$ & & \\
\hline$-(\mathrm{I}) \mathrm{w}$ & ішу & $\boldsymbol{V}$ & & & \\
\hline -GIs & ішкіс & & $\checkmark$ & & \\
\hline -(I)p & imin & & & $\checkmark$ & $\checkmark$ \\
\hline$-E$ & ime & & & $\checkmark$ & $\checkmark$ \\
\hline -GAlI & ішкелі & & & $\checkmark$ & $\checkmark$ \\
\hline -GAnfA & ішкенше & & & $\boldsymbol{V}$ & \\
\hline$-\mathrm{sA}$ & imce & & & $\checkmark$ & \\
\hline
\end{tabular}

\begin{tabular}{|c|c|c|c|c|c|}
\hline morpheme & example form & VN & VADJ & VADV & INF \\
\hline -GAn & эикән & $\checkmark$ & $\checkmark$ & & \\
\hline$-(\mathrm{V}) \mathrm{r}$ & эчәр & $\checkmark$ & $\checkmark$ & & \\
\hline -AcAK & эчәчәк & $\checkmark$ & $\checkmark$ & & \\
\hline$-(\mathrm{I}) \mathrm{w}$ & эи Ү & $\checkmark$ & & & \\
\hline$-\mathrm{mAK}$ & эчмәк & $\checkmark$ & & & \\
\hline$-E$ & эчә & & & & $\checkmark$ \\
\hline -(I)p & эиеп & & & $\checkmark$ & $\checkmark$ \\
\hline -GAncI & эчкәнче & & & $\checkmark$ & \\
\hline -GAc & эчкәи & & & $V$ & \\
\hline$-\mathrm{sA}$ & эчсә & & & $\boldsymbol{v}$ & \\
\hline
\end{tabular}

(c) Kazakh; example forms from the verb $i m$ - [э]] 'drink'. (d) Tatar; example forms from the verb э५- [эc] 'drink'.

\begin{tabular}{|c|c|c|c|c|c|}
\hline morpheme & example form & vN & VADJ & VADV & INF \\
\hline -GAn & ишкен & $\checkmark$ & $\checkmark$ & & \\
\hline$-(\mathrm{V}) \mathrm{r}$ & ижер & $\checkmark$ & 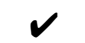 & & \\
\hline -GAlAK & ишкелек & $\checkmark$ & $\checkmark$ & & \\
\hline -GI dey & ишки дег & & 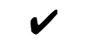 & $\checkmark$ & \\
\hline -GIze & ишкиже & $\boldsymbol{V}$ & & $\checkmark$ & \\
\hline$-(\mathrm{I}) \mathrm{p}$ & ижип & & & $\boldsymbol{V}$ & $\boldsymbol{V}$ \\
\hline$-E$ & иже & & & $\boldsymbol{v}$ & $\boldsymbol{v}$ \\
\hline -GAlA & ишкеле & & & $\boldsymbol{v}$ & \\
\hline -vI $\int A: n$ & ишпишаан & & & $\boldsymbol{V}$ & \\
\hline$-\mathrm{GA} \int$ & ишкеш & & & $\boldsymbol{v}$ & \\
\hline$-\mathrm{zA}$ & ишсе & & & $\boldsymbol{V}$ & \\
\hline
\end{tabular}

\begin{tabular}{|c|c|c|c|c|c|}
\hline morpheme & example form & $\mathrm{vN}$ & VADJ & VADV & INF \\
\hline -GAn & ичкен & $\boldsymbol{V}$ & $\boldsymbol{V}$ & & \\
\hline$-(\mathrm{A})(:) \mathrm{r}$ & ичээр & $\boldsymbol{V}$ & $\checkmark$ & & \\
\hline -E elek & иче элек & $\boldsymbol{V}$ & $\boldsymbol{V}$ & & \\
\hline$-(\mathrm{U}) \mathrm{U}$ & ичуУ & $\boldsymbol{V}$ & & & \\
\hline$-t g U$ & иччу & & $\checkmark$ & & \\
\hline -GIs & ичкис & & $\checkmark$ & & \\
\hline -(I)p & ичип & & & $\boldsymbol{\alpha}$ & $\boldsymbol{v}$ \\
\hline$-E$ & иче & & & 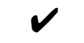 & $\boldsymbol{V}$ \\
\hline -GAnI & ичкени & & & $\boldsymbol{V}$ & $\boldsymbol{V}$ \\
\hline -GAntfA & ичкенче & & & $\checkmark$ & \\
\hline$-\mathrm{sA}$ & ичсе & & & $\checkmark$ & \\
\hline
\end{tabular}

(e) Tuvan; example forms from the verb uu- [if] 'drink'. (f) Kyrgyz; example forms from the verb $и ч$ - [itf] 'drink'.

Table 2: Morpho-syntactic properties of non-finite verb forms in six Turkic languages by suffix.

and the verb forms function as subjects either of verbs like /kel/- 'come' (Kyrgyz, etc.) or of adjectival predicates (via a copula) like /bar/ 'present' or /joq/ 'absent' (Uyghur, etc.). An example of each is shown in (10). ${ }^{12}$ However, volitional forms are much less versatile than other verbal noun forms in that they are limited to nominative case (i.e., they are always "bare", and never cooccur with any overt case marking) and

${ }^{12}$ It has been noted that the -/GI/ /GU/ suffix may be a borrowing from a different Turkic branch of a cognate to the verbal noun suffix in $-/(\mathrm{U}) \mathrm{U} / /(\mathrm{I}) \mathrm{w} /(\mathrm{cf}$. section 4.7). 
obligatorily take possessive morphology.

a. Volitional in Tatar
Күрәсем килә.
kyræsэm kilæ
kyг-EsI-(I)m kil-E
see-vn?-1sg come-NPST.3
'I want to see.'
b. Volitional in Uzbek
Ko'rgim bor.
kergim bpr
ker-gi-(i)m bbr- $\varnothing$
see-vN?-1sG present-COP.NPST.3
'I want to see.'

6.3. Compound verbs. The "level 3 converbs" discussed by Johanson (1995) are a type of construction where the two verbs both appear to contribute to valency and semantics in a way that is difficult to separate into two phrasal heads as in the case of a verbal adverb subordinate to another verb. According to Johanson, both verbs comprise individual "cores" of the predicate. It is not immediately clear how these Turkic V+V constructions fit into our typology. (11) presents an example discussed by Tyers et al. (2017).

$\begin{array}{llll}\text { Kazakh } & & & \\ \text { Мен кітапты } & \text { мектепке } & \text { алып } & \text { бардым. } \\ \text { miэn kэtaptə } & \text { misktiэpkiэ } & \text { ałəp } & \text { bardəm. } \\ \text { miэn kstap-NI } & \text { misktiэp-GA } & \text { al-(I)p } & \text { bar-DI-m. } \\ \text { I book-ACC } & \text { school-DAT } & \text { take-vADv? } & \text { go-PST-1sG } \\ \text { 'I brought the book to school.' } & & \end{array}$

In this sentence, the "level 3 converb" is the subordinate verb form 'take' in the construction. The adjunct 'to school' appears subordinate to apparent main verb 'go', whereas the argument 'book' is subordinate to 'take'. It cannot be said that aлbın [ałəp] is an infinitive form, since бар [bar] is not otherwise an auxiliary in Kazakh, and, regardless, contributes lexical meaning to the sentence. It is also difficult to assume that a asbin [ałəp] is a verbal adverb, since it does not form a contiguous constituent with its object kimanmbl [kstaptə]. Also, it should be noted that the sentence is not grammatical if a finite form of $a \Omega$ [ał] were used instead the non-finite form of $a \Omega$ [ał] with a finite form of бap [bar]-in other words, it is not possible to use a destination adjunct with $a \Omega[\mathrm{ał}]$ 'take'.

An alternative analysis of such constructions may be as lexicalised compound verbs, where aльи бар [ałəp bar] at some level acts as a single verb stem. While these may have their origins in constructions where a verbal adverb was dependent on a main verb head, they no longer function that way syntactically or semantically, despite retaining morphological evidence to that effect.

Further work is needed, then, to consider how an analysis of these constructions as compound verbs fits into a cross-linguistic perspective on compound verbs, and what implications that may have on our typology of non-finite verb morphology in Turkic.

6.4. Grammaticalisation. The historical relationship between various non-finite forms was not explored in this study. Since verbal nouns may be used adverbially with certain case markers or postpositions, it appears to be the case that these forms may (and do) grammaticalise to verbal adverbs, e.g. as a case suffix becomes less productive or as the semantics of the combination are no longer compositional. It may be hard to tell when a form has fully grammaticalised. A debatable example might be -/GAntfA/ 'until ing' in Kyrgyz, which would appear to be from the verbal noun suffix -/GAn/ and perhaps the adverbial -/ffA/ 'according to __ way'; since this suffix is not uncontroversially a case suffix or fully productive, it is easiest to think of the -/GAntfA/ suffix a grammaticalised verbal adverb form-though certainly one that has not yet fully lost its association with its origins.

Other directions which appear to be open for grammaticalisation include verbal noun forms and verbal adjective forms (which may become the other in part because of the ease in Turkic for nouns and adjectives to be used as heads of one another's phrases through a null head (cf. Washington \& Tyers 2017)), and infinitives seem in most cases to have grammaticalised from from verbal adverbs (as opposed to the other 
way around), likely related to the fact that the auxiliaries used with the infinitives are grammaticalised lexical verbs.

There is also a grammaticalisation relationship between certain Turkic non-finite verbs forms and many tense forms. Example 12 provides an example of this in Kazakh, where барғанмын [barвanmən], in form, looks like a verbal adjective or noun followed by a first person singular non-past copula, but has the semantics of 1 st person singular general past.

(12) Finite verb form grammaticalised from a non-finite verb form and copula in Kazakh

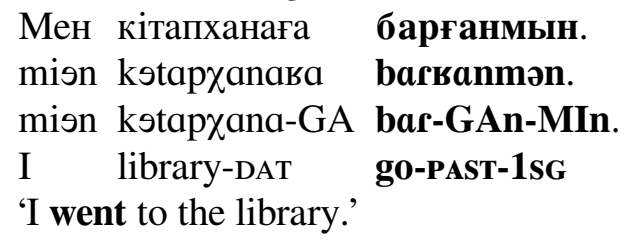

It is likely not right to say that forms like these are not finite verb forms-despite just that approach being taken by sources like Исхаков \& Пальмбах (1961) and Убрятова et al. (1982)—but there is a transparent relationship between forms like this and either a verbal noun or a verbal adjective followed by a copula. Similarly constructed tense forms where the copula surfaces as a separate, declined word are somewhat more difficult to deal with, per the discussion in Section 6.1.

7. Conclusions. Despite these open questions, we expect that delineating non-finite forms in Turkic languages based on their possible syntactic functions allows for additional clarity and consistency in cross-linguistic terminology. This framework, in fact, should be a point of departure for any analyses of these open questions, and likewise should jump-start new investigations of phenomena involving these verb forms. We further believe that this approach has the potential to lead to more straightforward analyses of —or at least a different perspective on-other phenomena of interest that involve non-finite verb forms, such as clause chaining (Dooley 2010), suspended affixation (Hankamer 2014), and verb-linking (Sugar 2019). Finally, we expect that this work will have practical benefits for automatic analysis of a wide range of Turkic languages which have been little discussed in the literature.

\section{References}

Anderson, Gregory \& K. David Harrison. 1999. Tyvan. Lincom Europa.

Asarina, Alya \& Jeremy Hartman. 2011. Genitive subject licensing in Uyghur subordinate clauses. In Andrew Simpson (ed.), Proc. of the 7th Workshop on Altaic Formal Linguistics (MIT Working Papers in Linguistics 62). http://web.mit.edu/alya/www/wafl-genitive-subjects-paper.pdf.

Csató, Éva Á. \& Muzappar Abdurusul Uchturpani. 2010. On Uyghur relative clauses. Turkic Languages 14. 69-93.

Danka, Balázs. 2018. Ambiguous [V+V] sequences in a 17th century Turkic variety. 19th Intl Conf on Turkish Linguistics: Collection of Abstracts. 18. https://sites.google.com/site/ictl19astana/program.

Demirci, Kerim. 2003. Descriptive verbs in Kazakh. University of Wisconsin Doctoral dissertation.

Dooley, Robert A. 2010. Exploring clause chaining. SIL Electronic Working Papers 2010-001.

Erdal, Marcel. 2004. A grammar of Old Tukic. Ledien: Brill.

Göksel, Aslı \& Celia Kerslake. 2005. Turkish: a comprehensive grammar. London: Routledge.

Hankamer, Jorge. 2014. Turkish suspended affixation. Presentation handout. Bloomington, Indiana.

Haspelmath, Martin. 2006. Coordination. In Timothy Shopen (ed.), Language typology and syntactic description, 1-51. Cambridge University Press.

Johanson, Lars. 1995. On Turkic converb clauses. In Martin Haspelmath \& Ekkehard König (eds.), Converbs in cross-linguistic perspective: structure and meaning of adverbial verb forms - adverbial participles, gerunds. Vol. 13 (Empirical approaches to language typology), 313-347. Berlin: de Gruyter. 
Johanson, Lars. 1998. The Structure of Turkic. In The Turkic Languages, chap. 3. Routledge. https : / / doi.org/10.4324/9780203066102.ch3.

Karakoç, Birsel. 2018. Ambiguity in Noghay multiverbal predications. 19th Intl Conf on Turkish Linguistics: Collection of Abstracts. 14-15. https://sites.google.com/site/ict119astana/program.

Kornfilt, Jaklin. 1997. Turkish. London \& New York: Routledge.

Krejci, Bonnie \& Lelia Glass. 2015. The Kazakh noun/adjective distinction. In Proc. of the 9th Workshop on Altaic Formal Linguistics (WAFL9).

Krueger, John R. 1961. Chuvash manual. Vol. 7 (Uralic \& Altaic Series). Bloomington: Indiana Univ.

Muhamedowa, Raihan. 2016. Kazakh: a comprehensive grammar. London: Routledge.

Nevskaya, Irina, Uldanay Jumabai \& Saule Tazhibayeva. 2018. Ambiguities in [V+V] sequences in Kazakh in comparison with South Siberian Turkic. 19th Intl Conf on Turkish Linguistics: Collection of Abstracts. https://sites.google.com/site/ictl19astana/program.

Popova, Natalya. 2018. Ambiguous VSs in Yakut. 19th Intl Conf on Turkish Linguistics: Collection of Abstracts. 29-30. https://sites.google.com/site/ictl19astana/program.

Ross, Daniel. 2016. Expressing adverbial relations in clause linkage with converbs: definitional and typological considerations. Syntax of the World's Languages 7, Workshop on Adverbial relations and clause linkages. http://hdl.handle.net/2142/91641.

Şaвdan uulu, Açьman \& I. A. Batmanov. 1933. Qbroqbz tilinin elementardıq oqramatikesi. Prunza, Taşkent: Qbrmemвas, Orasmemвas.

Sugar, Alexander Dylan. 2019. Verb-linking and events in syntax: the case of Uyghur -(i)p construction. University of Washington Doctoral dissertation.

Tyers, Francis M., Jonathan Washington, Çağrı Çöltekin \& Aibek Makazhanov. 2017. An assessment of universal dependency annotation guidelines for Turkic languages. Proc. of the Vth Intl Conf on Computer Processing of Turkic Languages (TurkLang 2017) I. 277-297. http://www . turklang . tatar / wp-content/uploads/2017/05/\%D0\%A2.1.pdf.

Washington, J. N., A. Bayyr-ool, A. Salchak \& F. M. Tyers. 2016. Development of a finite-state model for morphological processing of Tuvan. Родной Язык 1(4). 156-187. http :// rodyaz.ru/arhiv/ 4 2016.

Washington, Jonathan North, Ilnar Salimzyanov \& Francis M. Tyers. 2014. Finite-state morphological transducers for three Kypchak languages. In Proc. of the 9th Intl Conf on Language Resources and Evaluation, 3378-3385. http://www.lrec-conf.org/proceedings/lrec2014/summaries/1207.html.

Washington, Jonathan, Mirlan Ipasov \& Francis Tyers. 2012. A finite-state morphological transducer for Kyrgyz. In Proc. of the 8th Intl Conf on Language Resources and Evaluation (LREC'12), 934-940. http://www.lrec-conf.org/proceedings/lrec2012/summaries/1077.html.

Washington, Jonathan \& Francis Tyers. 2017. Towards a systematic functional description of Turkic nominal morphosyntax. Presentation at the Joint ESCAS-CESS Conference (Sixth Regional Conference of the Central Eurasian Studies Society) in Bishkek, Kyrgyzstan.

Ylikoski, Jussi. 2003. Defining non-finites: action nominals, converbs and infinitives. Suomen kielitieteellinen yhdistys Journal of Linguistics 16. 185-237.

Zúñiga, Fernando. 1998. Nomina sunt odiosa: a critique of the converb as a cross-linguistically valid category. Manuscript. Univ. of Zürich. http://zuniga.unibe.ch/down/Zuniga-converbs-1998.pdf.

Дыренкова, Н. П. 1941. Грамматика шорского языка. Москва: Академия наук СССР.

Исхаков, Ф. Г. \& А. А. Пальмбах. 1961. Грамматика тувинского языка: фбонетика и морфология. Москва: Издательство восточной литературы.

Убрятова, Е. И., Е. И. Коркина, Л. Н. Харитонов \& Н. Е. Петров. 1982. Грамматика современного якутского литературного языка. Vol. I: фонетика и морфология. Москва: Наука. 